\title{
FLEXURAL BEHAVIOR OF OSB REINFORCED WOOD TRUSS
}

\author{
Xiaojun Yang, Qi Zhao, Dan Hao, Jiayang Wang, Shuai Fu, Lan Ma \\ Nanjing Forestry University \\ Nanjing, JiAngsu,China \\ (Received July 2019)
}

\begin{abstract}
In this paper, oriented strand board (OSB) on both sides of the wood truss was used to strengthen the wood truss. The flexural behavior of the reinforced wood truss was studied. The results showed that OSB was an effective technical member to improve the flexural bearing capacity of wood truss. Besides, wood truss and OSB can be firmly combined by using glue bonding and screw connections. The screws served only to apply pressure to the glued joint. And the reinforced wood trusses had good synergy and overall stability. The initial bending stiffness and ultimate bending load of the reinforced wood trusses were increased by $203.20 \%$ and $234.39 \%$ respectively. Ultimate bending load and initial bending stiffness were improved a little by making the wood truss wider. Compared with the traditional wood truss, the reinforced wood truss had the advantages of simple connection mode, less wood consumption, no rolling machine and easy fabrication.
\end{abstract}

KEYWORDS: Wood truss reinforced with OSB, flexural behavior, lateral stability, stiffness.

\section{INTRODUCTION}

Wood construction has a long history. As early as 3000 years ago, the tenon-mortise structures were mainly used to connect beams and columns, forming a unique architecture style and contributing greatly to the world's architectural history. Nowadays, modern wood constructions are energy-saving, environment-friendly, safe and comfortable, which have been popularized in many areas all over the world (Lou et al. 2015, Liu et al. 2018, Yang et al. 2018, Wang et al. 2019, Zhang et al. 2019). With the rapid development of economy, people attach more and more importance to respecting nature and protecting environment. And higher requirements have been put forward for the living environment, which makes wood buildings have a good development prospect. For example, China is vigorously promoting sustainable development strategy, advocating low-carbon real estate and green buildings, which makes modern wood construction become a powerful factor in the future direction of domestic construction development. 
Wood members play an important role in wood construction, including columns, beams, stairs and other wood components. Wood beams are widely used in modern wood construction. The main types of them are solid wood beams and engineered wood beams. Solid wood beams have small range of application because it is easy to deform and crack. Besides, solid wood beams need to consume a lot of wood and its load-bearing performance requires prime wood properties. Engineered wood beams are made by modern wood processing methods, including glue laminated wood beams, laminated veneered lumber beams, parallel laminated wood beams, laminated stand lumber beams and so on (Ribeiro et al. 2009, Shi et al. 2017, Zhou et al. 2015, Ghanfh et al. 2017, Yehia et al. 2018, Wang et al. 2019, Xie et al. 2019). Engineered wood beams not only overcome many shortcomings of solid wood beams, but also can be designed in special sizes according to demand. In addition, they have many kinds of shapes. However, engineered wood beams need to be prefabricated in factories with complex technology. What's more, processing engineered wood beams needs large timber consumption and high cost.

Wood truss is a sort of wood frame system by using truss plates or nails to assemble and connect wood components. It is an important component of wood floor support and roof support. Besides, it has the advantages of light weight, high strength and good seismic performance (Song et al. 2010, Jin et al. 2015, Que et al. 2019). Wood truss mainly contains triangular truss and parallel chord truss. Wood truss has stable structure and changeable style. It can provide good bearing capacity under different conditions. For a long time, there have been many studies on wood truss, mainly in the form of wood truss structure, joint connection of wood truss, bearing capacity of wood truss and system combination effect of multi-trusses, etc. For the purpose of understanding the bearing capacity of light wood truss, the load carrying tests for light wood trusses with 6 meters span were carried out. Test results were compared with Chinese current code for design of wood constructions and several major factors which influence the bearing capacity of light wood truss were analyzed (Xu et al. 2006). In order to quantitatively recognize the properties of light wood truss assembly, the system effect and its influential factors for light wood truss assembly with a random sampling simulation method were analyzed. The result showed that the system effect of light wood truss assembly was mainly influenced by the failure mode, system volume, boundary supporting condition as well as correlation between elastic modulus and strength of dimension lumber (Huang et al. 2011). In Auburn University, a wood truss ladder that moved truss from the ground to the level was examined. A prototype version of the truss ladder was constructed and tested at two residential housing projects. Speed, ease of use, safety, and worker fatigue were investigated for these two projects using qualitative measures. The truss lifter offers potential increases in safety and reduced worker fatigue (Farrow 2009). These studies are almost based on the use of mechanical theory or finite element method with specification timber as members (Hoyle 1985, Hunt 2004, Song et al. 2012, Wu et al. 2018). This paper arranges the wood truss specifications along the wide plane, strengthens the wood truss by applying OSB on both sides of the wood truss to study its initial bending stiffness and develop large cross-section wood beams suitable for construction site, which is of great significance to promote the development of modern wood construction.

\section{EXPERIMENT AND METHODS}

\section{Materials}

The wood species used in the study was pine (Pinus spp.) in the category of SPF (sprucepine-fir). OSB with dimension of $15 \mathrm{~mm}$ in depth was used as reinforced material, with a static 
bending strength ( // ) of $30 \mathrm{MPa}$, a static bending strength $(\perp)$ of $18 \mathrm{MPa}$, a modulus of elasticity $(\mathrm{MOE} / /) 3600 \mathrm{MPa}$, a modulus of elasticity (MOE $\perp) 1500 \mathrm{MPa}$ and an internal bonding strength of $0.41 \mathrm{MPa}$.

Chamfer screw (mode: cl- $38 \times 2.2$ and cl- $80 \times 3.4$ ) were used in the test, which were widely used in the joint of wood products with high stiffness. The adhesive used in the test was a single component polyurethane (type: R645/30, producer: H.B. Fuller Co., Ltd). Deformations were measured by 7 resistance strain gauges (type: BF350-6AA, producer: Guangzhou Zheyuan Electronics Co., Ltd) with a nominal resistance of $350 \Omega$, a sensitivity of $2.11+1 \%$, an accuracy grade A and a base size of $9.6 \times 3.5 \mathrm{~mm}$. The resistance strain gauges were fixed by cyanoacrylate adhesive. And the placement was shown in Fig. 3.

The test was carried out using a universal testing machine (type: UTM5105, producer: Shenzhen Suns Technology Stock Co., Ltd.) and resistance strain instrument (type: TDS-530, Producer: Tokyo Sokki Kenyujo Co., Ltd.).

\section{Experimental design}

OSB reinforced wood truss (Fig. 1) was composed of wood truss and OSB boards on both sides. The wood truss was made up of $2 \times 4$ inches or $2 \times 6$ inches dimension lumber (Pinus spp). It was connected by screw with dimension of $80 \mathrm{~mm}$ in length and $3.4 \mathrm{~mm}$ in diameter. The spacing of truss internode was $253 \mathrm{~mm}$, the height of truss was $200 \mathrm{~mm}$, the angle between chord and web member was $30^{\circ}$, and the lateral OSB was fixed by screw with dimension of $38 \mathrm{~mm}$ in length and $2.2 \mathrm{~mm}$ in diameter.

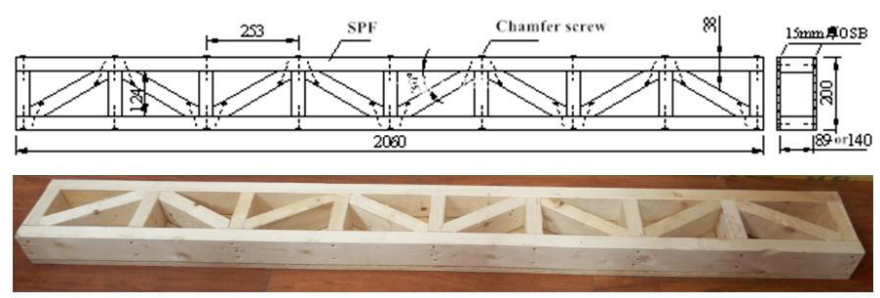

Fig. 1: Structure of reinforced timber truss using OSB.

Tab. 1: Specimen of reinforced timber truss using OSB.

\begin{tabular}{|l|c|c|c|c|c|}
\hline $\begin{array}{c}\text { Experimental } \\
\text { group }\end{array}$ & $\begin{array}{c}\text { Specification } \\
\text { of rod }\end{array}$ & $\begin{array}{c}\text { Connection } \\
\text { between rods }\end{array}$ & $\begin{array}{c}\text { Reinforcement } \\
\text { pattern }\end{array}$ & $\begin{array}{c}\text { OSB } \\
\text { connection mode }\end{array}$ & $\begin{array}{c}\text { OSB nail } \\
\text { connection section }\end{array}$ \\
\hline C-Z & $2 \times 4$ inch & Truss plate & - & - & - \\
\hline D-L & $2 \times 4$ inch & Chamfer screw & $\begin{array}{c}\text { OSB } \\
\text { reinforcement }\end{array}$ & Nailed joint & $\begin{array}{c}\text { Chord and web } \\
\text { member }\end{array}$ \\
\hline J-D-X & $2 \times 4$ inch & Chamfer screw & $\begin{array}{c}\text { OSB } \\
\text { reinforcement }\end{array}$ & $\begin{array}{c}\text { Glue connection+ } \\
\text { nail connection }\end{array}$ & chord \\
\hline J-D-XF-K & $2 \times 4$ inch & Chamfer screw & $\begin{array}{c}\text { OSB } \\
\text { reinforcement }\end{array}$ & $\begin{array}{c}\text { Glue connection } \\
\text { +nail connection }\end{array}$ & $\begin{array}{c}\text { Chord and web } \\
\text { member }\end{array}$ \\
\hline
\end{tabular}

Notes: “-” Indicates no reinforcement or nonexistence.

The wood truss test was divided into five groups (Tab. 1). There were three specimens in each group. The first group to the fourth group were made of $2 \times 4$ inches lumber. The first 
group was not reinforced in accordance to Chinese Nation Standard (JGJ/T 265-2012). It was connected by galvanized truss plate as a reference control group, numbered C-Z. In group 2, OSB reinforcement group was connected with nails, which was fixed by nails at the upper, lower chord and web rod parts. The nail spacing at the chord part was $150 \mathrm{~mm}$, and the nail spacing at the web rod part was $100 \mathrm{~mm}$. The number was D-L. The third group was the OSB reinforcement group with glue and chord nails, which was coated with polyurethane glue on both sides of the wood truss, and fixed OSB reinforcement wood truss with nails at the chord position. The nail spacing was $150 \mathrm{~mm}$, numbered J-D-X. The fourth group was OSB reinforcement group with glue connection + nail connection located in whole truss. The spacing between chord nail and web nail was $150 \mathrm{~mm}$ and $100 \mathrm{~mm}$ respectively. The number was J-D-XF. The fifth group was the $2 \times 6$ inches wood truss reinforcement group. The two sides of the wood truss made of $2 \times 6$ inches dimension lumber were coated with polyurethane glue, and OSB-reinforced wood truss was fixed with nails at the chord and web, the nail spacing at the chord was $150 \mathrm{~mm}$, and the nail spacing at the web was $100 \mathrm{~mm}$, numbered J-D-XF-K. The arrangement of nails fixed in wood truss was shown in Fig. 2.

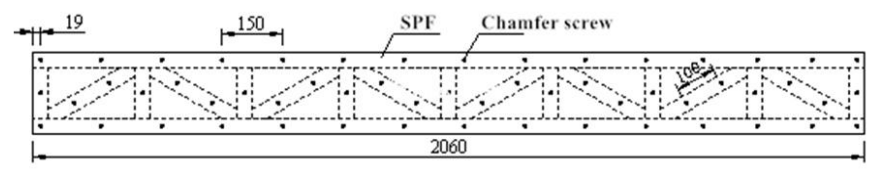

Fig. 2: Layout of screws in wood truss's lateral.

The bending performance test was carried out according to the Chinese National Standard (GB/T 50329-2012). The loading speed was uniform of $10 \mathrm{~mm} \cdot \mathrm{min}^{-1}$. In order to understand the deformation of the mid-span section along the height of the cross-section, seven strain gauges were arranged in the mid-span of each specimen, one on the upper and lower surfaces of the wood truss, and five on the equal spacing along the height direction, with the spacing of $30 \mathrm{~mm}$. In order to understand the deformation of the wood truss during the loading process, displacement gauge were arranged at the bottom of the specimen span and the side of the wood truss under the pressure head of the testing machine. The bottom displacement gauge were fixed on the base of the testing machine and the lateral displacement gauge were fixed on the cross beam of the pressing head of the testing machine. Two lateral displacement gauge were arranged on both sides of the wood truss, and their position numbers were QS-1, QX-1, BS-2 and BX-2. The arrangement of strain gauges and displacement gauges was shown in Fig. 3.

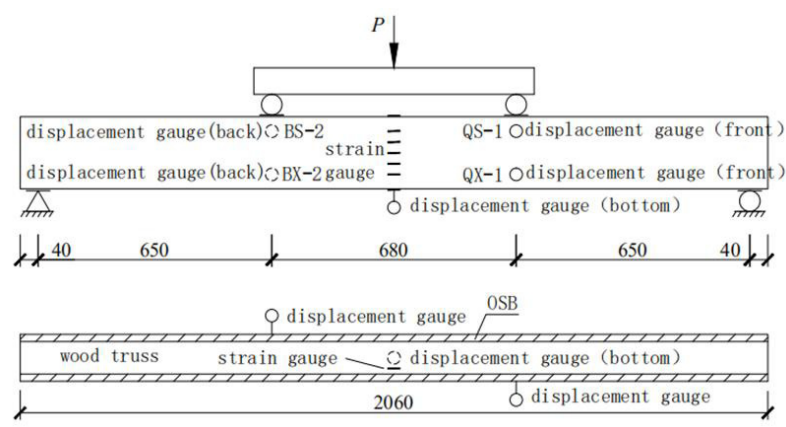

Fig. 3: Layout of displacement gauge and strain gauge. 


\section{RESULTS AND DISSCUSSION}

As shown in Fig. 4, the load-deflection curve of reinforced wood truss showed almost the same regulation as that of reference group. At the initial stage of loading, the specimen was basically in an elastic state. The load increased linearly with the increase of displacement. At the stage of loading approaching the limit value, the specimen showed a certain plastic deformation. The stiffness decreased and the deformation tended to be obvious. The load decreased rapidly with large sound of local fracture. When the load of each reinforcement group reached the limit value, the deflection was $21.29 \mathrm{~mm}-28.68 \mathrm{~mm}$. The slope of the curve in the early stage of loading was significantly different between the reinforcement group and the reference group. The slope of the curve in C-Z group was gentle, while that in J-D-X group, J-D-XF group and J-D-XF-K group was steep, and that in D-L group was in the middle. According to the Chinese National Standard (GB50005-2017), when the deflection limit of C-Z, D-L, J-D-X, J-D-XF and J-D-XF-K wood trusses reached 1/150, the loads of each group were $8.8 \mathrm{kN}, 13.37 \mathrm{kN}$, $25.96 \mathrm{kN}, 27.18 \mathrm{kN}$ and $28.25 \mathrm{kN}$, respectively. Compared with the reference group, the loadbearing capacity of each reinforcement group was greatly improved when the deflection limit was specified.

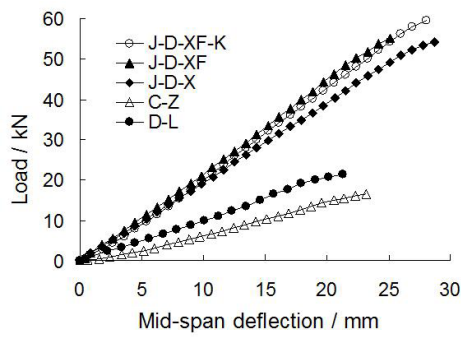

Fig. 4: Load deflection curves of typical wood trusses.

The failure characteristics of wood truss specimens in reinforcement group were shown in Fig. 5. Before the failure, there was obvious screw-bending noise caused by nail yielding in D-L group and obvious lateral deformation of OSB plates on both sides of wood truss. The failure of the specimens showed that the middle part of the tension zone of the OSB plate was broken and the web of the wood truss collapsed obviously. The failure of J-D-X group showed nail bending deformation, cracking of upper edge adhesive layer between OSB and wood truss, breaking of lower edge OSB and intact lower chord. Before the failure of J-D-XF group, there was intermittent sound of wood fiber brittle fracture. After the failure of the sample, the upper edge of OSB was extruded and uplifted. The lower edge of OSB was broken with the lower chord of wood truss, and the fracture location was adjacent. The failure modes of J-D-XF-K were similar to those of J-D-XF group, which showed OSB compression failure at upper and middle edges, $\mathrm{OSB}$ and lower chord fracture at lower edges.

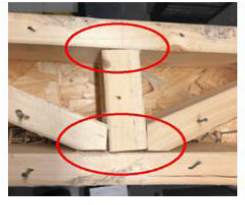

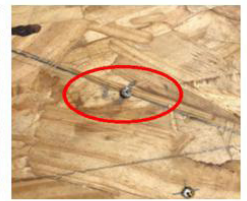

(a) D-L group

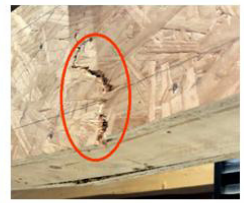

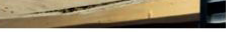



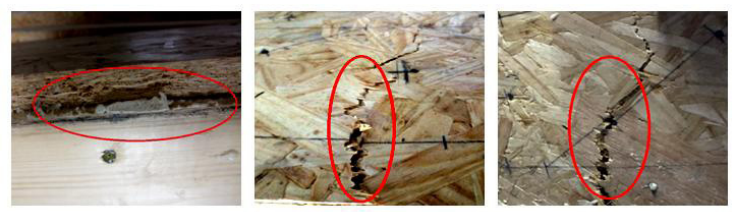

(b) J-D-X group
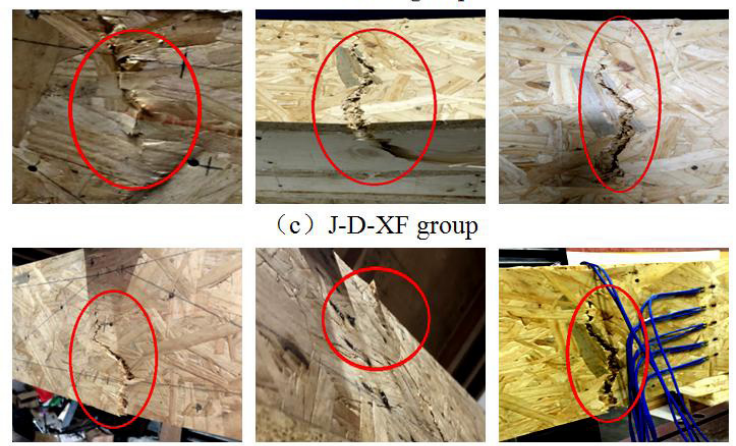

(c) J-D-XF group
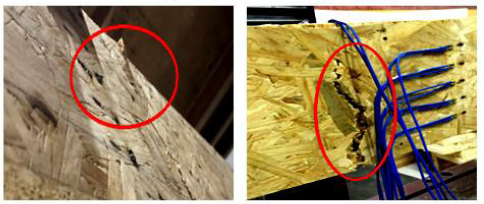

(d) J-D-XF-K group

Fig. 5: Typical failure modes of specimens.

According to the load and deflection changes of reinforced wood truss in the elastic range, the initial bending stiffness of reinforced wood truss was calculated. The initial stiffness was the linear slope of $10 \%$ to $40 \%$ of the ultimate load on the load-displacement curve. The stiffness of each group of specimens was as shown in Tab. 2.

Tab. 2: Flexural capacity and initial stiffness of reinforced timber truss using OSB.

\begin{tabular}{|l|c|c|c|c|}
\hline \multicolumn{1}{|c|}{ Number } & $\begin{array}{c}\text { Ultimate load } \\
(\mathrm{kN})\end{array}$ & $\begin{array}{c}1 / 150 \text { Deflection } \\
\text { limit load }(\mathrm{kN})\end{array}$ & $\begin{array}{c}\text { Limited deflections } \\
(\mathrm{mm})\end{array}$ & $\begin{array}{c}\text { Initial stiffness } \\
\left(\mathrm{N} \cdot \mathrm{mm}^{-1}\right)\end{array}$ \\
\hline $\mathrm{C}-\mathrm{Z}$ & 16.46 & 8.80 & 23.18 & 708.21 \\
\hline $\mathrm{D}-\mathrm{L}$ & 21.39 & 13.37 & 21.29 & 964.95 \\
\hline J-D-X & 54.25 & 25.96 & 28.68 & 1942.38 \\
\hline J-D-XF & 55.04 & 27.18 & 25.09 & 2147.26 \\
\hline J-D-XF-K & 59.71 & 28.25 & 28.03 & 2083.47 \\
\hline
\end{tabular}

From Tab. 2, it could be seen that the ultimate load and initial stiffness of OSB reinforcement group were significantly higher than those of the reference group. The ultimate load of D-L, J-D-X, J-D-XF and J-D-XF-K in the reinforcement group was 29.95\%, 229.59\%, $234.39 \%$ and $262.76 \%$ higher than that of the reference group, respectively. The limit load of $1 / 150$ deflection was $51.93 \%, 195.00 \%, 208.86 \%$ and $221.02 \%$ higher than that of the reference group, and the initial stiffness was $36.25 \%, 174.27 \%, 203.20 \%$ and $194.19 \%$, respectively. The bearing capacity and initial stiffness of the reinforcement groups differed significantly due to the different reinforcement modes. As a conventional method, the flexural capacity and stiffness of reference group wood truss were general. The flexural load-bearing capacity of wood truss could be significantly improved by compounding OSB boards on the side of the truss.

For the D-L group, the flexural capacity was improved the least. For one thing, nail connection was used between the members of wood truss, which was weaker than that of 
reference group. For another thing, nail connection composite OSB which was the weak part of destruction was difficult to play the synergistic role between OSB and wood truss. When bending, the interaction between OSB and wood truss on both sides was less. The bearing capacity was mainly provided by OSB side plate. The shear force of nail joint was huge.

For the J-D-X group, the ultimate load and bending stiffness were 2.54 and 2.01 times higher than those of the D-L group, respectively. The polyurethane structural adhesives coated on the chord had remarkable improvement in bending resistance. OSB and wood truss had good synergy. The nails when bonding ensured that OSB and wood truss chord were fully bonded and compounded under certain pressure. In addition, the polyurethane adhesives used in the curing process would foam and expand, which could fully fill some uneven surfaces and cracks on the side of the truss and bond firmly. OSB contributed a lot to the flexural capacity of wood truss.

For the J-D-XF group, the ultimate load and flexural stiffness were 1.01 and 1.11 times higher than those of the J-D-X group, respectively, and the increase was not obvious. The gluing of web members of wood truss contributed a little to the whole, mainly supporting web members and reducing the flexural capacity of nail joints between chord and web members. The web member region played a supporting and connecting role, while the upper and lower chords played a bending role.

For the J-D-XF-K group, both of them adopt the same reinforcement composite method. The former used $2 \times 6$ inches of dimension stock and the latter $2 \times 4$ inches of dimension stock. When the width of wood truss increased, larger support surface could be obtained. However, the flexural performance could not be improved. The ultimate load of the former was slightly higher than that of the latter, while the initial stiffness of the former was slightly lower than that of the latter. The ultimate load was slightly higher and the initial stiffness was slightly lower, which indicated that the bending stiffness mainly depended on the OSB plates on both sides of the wood truss. The contribution of OSB to flexural capacity was not obvious with the increase of width, and the dimension of width direction was not the key factor affecting the bending performance.
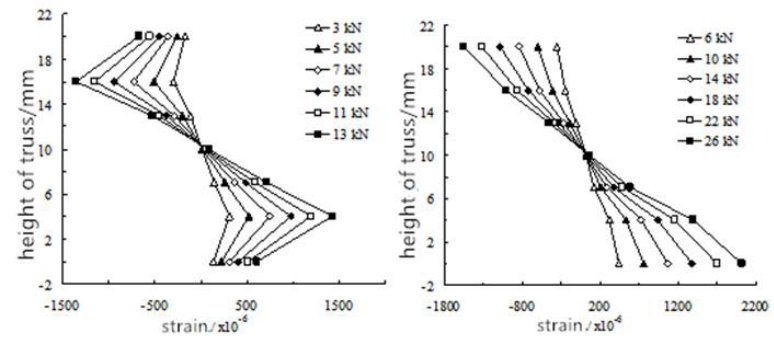

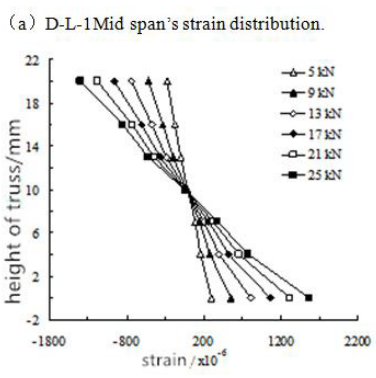

(c) J-D-XF-1Mid span's strain distribution (b) J-D-X-1 Mid span's strain distribution.

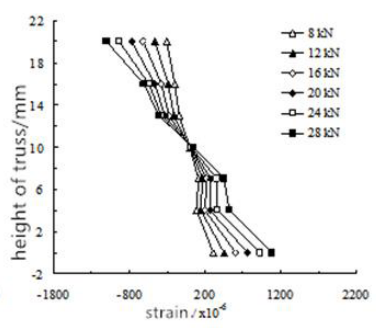

(d) J-D-XF-K-1Mid span's strain distribution.

Fig. 6: Mid span's strain distribution of typical wood truss reinforced with OSB. 
From Fig. 6, it could be seen that the strain distribution along the cross-section height of D-L group wood truss was significantly different from that of J-D-X group, J-D-XF group and $\mathrm{J}-\mathrm{D}-\mathrm{XF}-\mathrm{K}$ group in the process of loading in the elastic range. The strain distribution of upper and lower chords of wood truss was not linear with that of the intermediate strain of wood truss. The key to stress transfer between plates was that the poor rigidity of nail joints easily lead to the inconsistency of the overall synergy between OSB and upper and lower chords of wood truss as well as the obvious difference of strain distribution occurs at lower loads.

The strain distribution in the span of J-D-X group and J-D-XF group was almost the same. Both groups adopt the reinforcement mode of nail connection fixation and structural bonding fixation OSB. The former was glued on the upper and lower chords, while the latter was glued on the chord and web. Structural adhesives were single-component polyurethane adhesives. Structural adhesives were commonly used for structural materials with high bonding strength. OSB and wood truss were firmly bonded. The bonding surface bear the stress transfer between wood truss and OSB board. The linear distribution of mid-span strain indicated that OSB and wood truss have good synergy and synchronization in the process of loading in the elastic range, and the material difference in different parts has little influence on the strain distribution. In the composite process of OSB and wood truss, nails could make the glued OSB and wood truss adhere closely and achieve firm bonding.

The strain in the span of J-D-XF-K group wood truss approximated linear distribution, and the group adopts the reinforcement mode of pin connection fixation and structural glue full surface bonding fixation OSB. The wood truss was made of $2 \times 6$ inch large size timber, and the strain value under each load was smaller than that of J-D-XF group wood truss under the same composite condition. The strain distribution of OSB on the side of wood truss was a little irregular. Wider specification timber was used in the wood truss, which accounts for a large proportion in the overall truss. OSB was obviously affected by the web member of the wood truss.
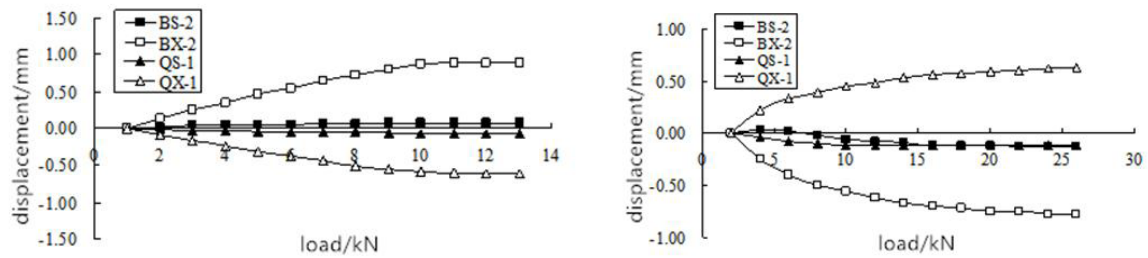

Fig. 7: Lateral displacement variation of typical Fig. 8: Lateral displacement variation of typical wood truss in D-L group.
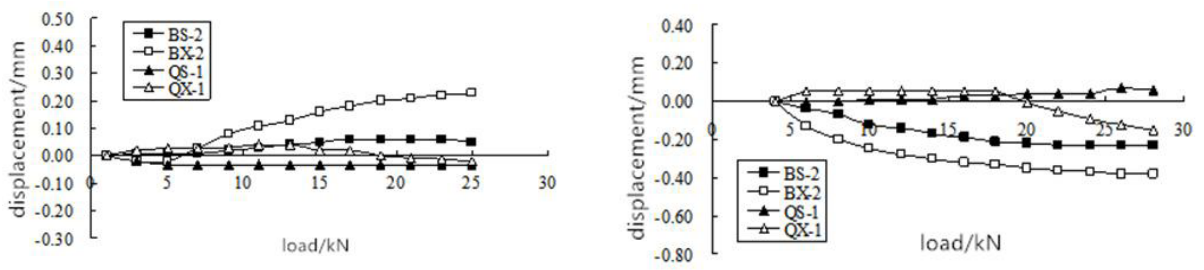

Fig. 9: Lateral displacement variation of typical wood truss in J-D-XF group.

Fig. 10: Lateral displacement variation of typical timber truss in J-D $X F-K$ group. 
From Fig. 7 to Fig. 10, it could be seen that the lateral displacement of each position on both sides of the reinforced wood truss increased with the increase of load. The trend of lateral displacement of the upper edge of the truss was similar. It fluctuated in a small range of $(+0.1 \mathrm{~mm})$. The lower edge of the truss was pulled under compression, the upper edge was compressed. And the bending stiffness of OSB plate in a small plane was found in a small deformation range with the truss under load. The change trend of lateral displacement at the lower edge position was distinct. The lateral displacement of the lower edge of the truss under the indentation head varied greatly in both D-L group and J-D-X group. One side of the truss deformed inward and the other side expanded outward. Truss and OSB plate had smaller mutual restraint force. When OSB plate was bent in plane, the ratio of height to width of section was 13:1. The compression part of OSB plate was prone to buckling along the plane with smaller stiffness. However, because of the continuous restraint of the tension part along the length direction, the compression part would move sidewise while driving the whole section to twist, which ultimately lead to a certain degree of bending and torsion deformation of OSB plate. In addition, the composite technology and internal stress of reinforced wood truss were also important factors affecting the overall lateral stability and overall performance of reinforced wood truss. The deformation of the lower lateral protrusion and depression in group $\mathrm{D}-\mathrm{L}$ was significantly larger than that in group J-D-X. In group J-D-X, structural bonding was used between OSB and truss chord during composite, which partially restrained the lateral deformation of OSB cladding.

$\mathrm{J}-\mathrm{D}-\mathrm{XF}$ group was similar to J-D-XF-K group in wood truss, and lateral displacement varied in a small range. Both groups used nail connection and full surface glue bonding between wood truss and OSB board. The bonding between cladding board and web bar and chord bar was firm. The possibility of lateral deformation was greatly reduced under load. The range of lateral displacement fluctuation was related to the fabrication of wood truss members, the accuracy of joints of wood truss members, the symmetry of cover plates on both sides of the truss and the rebalancing of internal stress. The lateral ultimate displacement of the wood truss in J-D-XF-K group was slightly larger than that in J-D-XF group, but both of them were in the range of $\pm 0.4 \mathrm{~mm}$. According to the failure characteristics of the samples, there was no obvious warping or lamination of OSB plates on both sides during the failure. The lateral stability of the wood truss was good. And the small variation of lateral displacement had little effect on the overall workability of the reinforced wood truss.

During the past few decades, researchers and engineers have been constantly exploring engineering wood materials that can replace solid wood beams. The wood truss reinforced with OSB has large bearing capacity and rigidity which is close to other studies analyzing the mechanical properties of CFRP-reinforced wood beams or other composite beams (Issa et al. 2005, Li et al. 2009, Nadir et al. 2016). It is a light-weight high-strength large-section wood beam. In addition, it can be obtained by simple processing of dimension lumbers and also be put into use on-site construction. To some extent, the reinforced wood truss can take the place of some wood beams in wood structure engineering.

\section{CONLUSIONS}

(1) Using OSB on both sides of the wood truss was an effective technical means to improve the flexural bearing capacity of wood truss. Compared with the common wood truss, the initial bending stiffness and ultimate bending load of the reinforced wood truss was greatly improved by using OSB through screw connection and full surface glue bonding. 
(2) Within the elastic range, the strain variation trend of the mid-span section could reflect the synergy between OSB and wood truss. The synergy between OSB and wood truss is better by using nail bonding and chord bonding or full surface bonding. The strain variation of midspan section along the beam height is always linear. The glued joint is stiff while nailing joints is not. There is no long-term synergy between the screws and adhesives on which we can build a long-term safety. The screws in the glued joints serve only to apply pressure to the glued joint.

(3) The change trend of lateral displacement of wood truss could reflect the lateral stability of wood truss. The lateral stability of wood truss is better by means of nail bonding and fullsurface glue bonding. The lateral displacement fluctuates in a small range and the overall effect was strong, showing good overall performance.

(4) Composite mode was the decisive factor of OSB enhancement effect. The reinforcement effect of wood truss was not ideal and the lateral stability was poor when OSB was combined with nail connection. The ultimate bending load and initial bending stiffness of reinforced wood truss was improved significantly by using nail connection and chord glue bonding, but the lateral stability was general, and local OSB delamination and peeling were easy to occur. With nail bonding and full surface glue bonding, the wood truss had the best reinforcement effect and the overall working performance was greatly improved. The bending failure modes of reinforced wood truss were mainly OSB extrusion uplift, OSB at lower edge and OSB at lower chord tie rod break or OSB at lower edge nail break, and no OSB peeling and delamination phenomenon occurs. The ultimate bending load increased slightly with the increase of section width of reinforced wood truss, and the contribution to the initial bending stiffness was small.

(5) The connection of reinforced wood truss was simpler than that of conventional wood truss. Reinforced wood truss did not need truss plate rolling machine. And it was convenient for site construction and consumed less wood. Besides, large cross-section solid wood beam can be replaced by reinforced wood truss. Thus, reinforced wood truss could be used in wood construction engineering.

\section{ACKONWLEGEMENT}

This work was supported by Nanjing Senzhihu Construction Engineering Co., Ltd.

\section{REFERENCES}

1. Farrow, C.B., 2009: Evaluation of a prototypical mechanical wood truss ladder. Automation in Construction 18: 1114-1122.

2. Ghaneh, M., Behbood, M., Ghanbar, E., 2017: Glulam beam made from hydrothermally treated poplar wood with reduced moisture induced stresses. Journal of Construction and Building Materials 135: 386- 393.

3. Hoyle, R.J., Griffith, M.C., Itani, R.Y., 1985: Primary creep in Douglas fir beams of commercial size and quality. Wood and Fiber Science 17: 300-313.

4. Huang H., He M.J., Zhou S.R., Cui J., 2011: System effect analysis of light wood truss assembly. Journal of Shenyang University of Technology 33(3): 343-348 (In Chinese).

5. Hunt, D.G., 2004: The prediction of long-time viscoelastic creep from short-time data. Wood Science and Technology 38: 479-492. 
6. Issa C.A., Kmeid Z., 2005: Advanced wood engineering: Glulam beams. Construction \& Building Materials 19(2): 99-106.

7. Jin M.M., Hu Y.C., Wang B., 2015: Compressive and bending behaviours of woodbased two-dimensional lattice truss core sandwich structures. Composite Structures 124: 337-344.

8. Li Y.F., Xie Y.M., Tsai M.J., 2009: Enhancement of the flexural performance of retrofitted wood beams using CFRP composite sheets. Construction \& Building Materials 23(1): 411-422.

9. Liu, M.B., Sun, Y.F., Sun, C., 2018: Study on thermal insulation and heat transfer properties of wood frame walls. Journal of Wood Research 63: 249-260.

10. Lou, W.L., Ren, H.Q. 2015: Characteristics and prospects of wood structure buildings in China. Journal of Wood Industry 29: 20-23. (In Chinese).

11. Nadir Y., Nagarajan P., Ameen M., Arif M.M., 2016: Flexural stiffness and strength enhancement of horizontally glued laminated wood beams with GFRP and CFRP composite sheets. Construction and Building Materials 112: 547-555.

12. Que Z.L., Hou T.Y., Gao Y.F., Teng Q.C., Chen Q.Y., Wang C.J., Chang C., 2019: Influence of different connection types on mechanical behavior of girder trusses. Journal of Bioresources and Bioproducts 4(2): 89-98.

13. Ribeiro, A.S., de Jesus, A.M.P., Lima, A.M., Lousada, J.L.C., 2009: Study of strengthening solutions for glued-laminated wood beams of Maritime pine wood. Journal of Construction and Building Materials 23(8): 2738-2745.

14. Shi H.Y., Liu W.Q. Fang H., Bai Y., Hui D., 2017: Flexural responses and pseudo-ductile performance of lattice-web reinforced GFRP-wood sandwich beams. Composites Part B 108: 364-376.

15. Song X.B., Lam F., 2012: Stability analysis of metal-plate-connected wood truss assemblies. Journal of Structural Engineering 138: 1110-1119.

16. Song X.B., Lam F., Huang H., He M.J., 2010: Stability capacity of metal plate connected wood truss assemblies, Journal of Structural Engineering 136(6): 723-730.

17. Wang F.B., Wang X.M., Cai W.Z., Chang C., Que Z.L., 2019: Effect of inclined selftapping screws connecting laminated veneer lumber on the shear resistance. BioResources 14(2): 4006-4021.

18. Wang, Z., Lu, Y., Xie W.B., Gao. Z.Z., Ging Y.W., Fu H.Y., 2019: Shear stress analysis interlayer shear strength test of cross laminated timber (CLT) beam. Journal of Scientia Silvae Sinicae 55: 157-164.

19. Wu Y., Xiao, Y., 2018: Steel and glulam hybrid space truss. Engineering Structures 171: $140-153$.

20. Xie, W.B., Lu, Y., Wang, Z., Wang X.W., Wu, X.L., Gao, Z.Z., 2019: Feasibility of predictive assessment of bending performance of CLT plates of Canadian hemlock. Journal of bioresources 14: 6047-6059.

21. Xu X.L., Ma R.L., He M.J., 2006: Static test and load capacity of lightweight wooden truss. Special Structures 23(1): 1-4 (In Chinese).

22. Yang, X.J., Ma, L., Zhao, Q. 2018: Screw connection in wood members and WPC members. Wood Research 63: 833-841.

23. Yehia A., Zaher A., 2018: Flexural behavior of FRP strengthened concrete-wood composite beams. Ain Shams Engineering Journal 9: 3419-3424.

24. Zhang X.F., Luo L.S., Fu H.Y., Sun Y.F., Hui X.R., 2019: Experimental investigation into the flexural behavior of hollow, full, and intermittently stiffened (bamboo-like) glulam beams from larch wood. BioResources 14(1): 2171-2185. 
25. Zhou, X.Y., Cao, L., Zeng, D., 2015: Flexural capacity analysis of glulam beams. Journal of Building Structures 45: 91-96. (in Chinese).

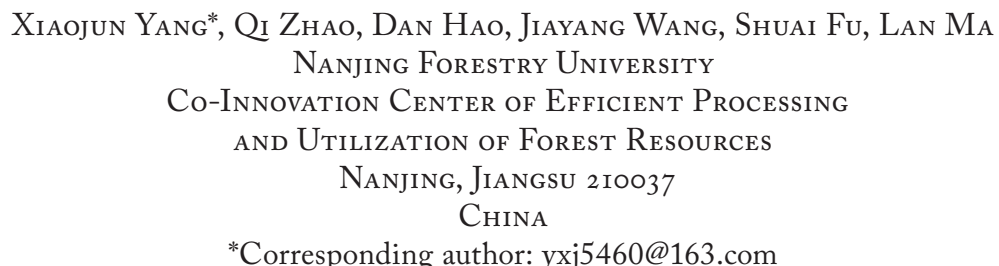

